\title{
A positive legacy - against all odds Olympic facilities at the 1994 Olympic Winter Games
}

\author{
Dag Vidar Hanstad ${ }^{1,2, *}$ \& Jon Helge Lesjø² \\ 1 Department of Sport and Social Sciences, Norwegian School of Sport Sciences, Oslo, Norway \\ 2 School of Business and Social Sciences, Inland Norway University of Applied Sciences, Lillehammer, Norway \\ * Corresponding author: Norwegian School of Sport Sciences, P.O. Box 4014 Ullevaal Stadion, N-0806 Oslo, Norway \\ Tel.: +47 90892229 \\ E-Mail: d.v.hanstad@nih.no
}

\section{ORIGINAL ARTICLE}

\section{Article History:}

Submitted $9^{\text {th }}$ March 2020

Accepted $16^{\text {th }}$ October 2020

Published $18^{\text {th }}$ November 2020

Handling Editor:

Martin Kopp

University of Innsbruck, Austria

Editor-in-Chief:

Martin Kopp

University of Innsbruck, Austria

Reviewers:

Reviewer 1: anonymous

Reviewer 2: anonymous

\section{ABSTRACT}

The aim of this study is to explore the concept of legacy in mega sporting events. More precisely, it examines how one of the smallest cities to host the Olympic Winter Games, Lillehammer in 1994, more than 25 years after the Games, has a rather positive legacy of the investments in sporting facilities, opposite to a majority among the hosts of the Winter Games. The research, which entailed qualitative documentary analysis (e.g. bidding documents, government guarantees, propositions and minutes of meetings in the Parliament, supplemented with interviews), shows how the concept was changed after Lillehammer was awarded the event in 1988. Lillehammer went from an extreme compact Games model to place the venues in five municipalities. Also important was the establishment of government funding to maintain the different arenas. For many hosts of mega/major events, sport facilities end up with a negative legacy because of poor or insufficient planning. Today, the 'after-use fund' has been depleted, which is challenging for Lillehammer because several municipalities in the Olympic region are also responsible for the funding. It remains to be seen if the positive legacy will remain positive in the years to come.

Keywords:

Legacy - Winter Olympic Games - Sport Facilities - The International Olympic Committee

Citation:

Hanstad, D. V. \& Lesjø, J. H. (2020). A positive legacy - against all odds. Olympic facilities at the 1994 Olympic Winter Games. Current Issues in Sport Science, 5:008. doi: 10.36950/2020ciss008.

\section{Introduction}

At the closing ceremony of the 1994 Olympic Winter Games in Lillehammer, Norway, the president of the International Olympic Committee (IOC), Juan Antonio Samaranch, announced that Lillehammer had been 'the best Olympic Winter Games ever' (Haugerud, 2015). Later, Samaranch said: 'We never before had seen the participation of the population in the Olympic Games like we saw in Norway. Never. To have the Games in such a small city!'1 Michael Payne, an IOC director between 1988 and 2005, claimed that Lillehammer turned the spectators into part of the spectacle. 'This and the overall look of the Games exceeded everyone's expectations' (Payne, 2005, p. 172). The impression of successful Games reached outside the IOC headquarters in Lausanne, Switzerland. Sports Illustrated stated:'These were the fairy-tale Games, drawn from the imagination, staged in the pages of a children's book. They could not exist. Reality cannot be this good' (Montville, 1994, p. 90).

Why do the Lillehammer Games have such a positive image? Is the impression the same more than 25 years later? Did the organizer, unlike most Olympic hosts, manage to plan in such a good way that the legacy is essentially positive, or is this a matter of coin-

1 Interview with one of the authors in Barcelona, June 15, 2005. 
cidences? Insight into the legacy of Lillehammer is poor because hardly any papers have been published on the topic (Scheu, Preuss, \& Könecke, 2019). This paper will fill some gaps.

The point of departure is Preuss' definition of legacy: 'Irrespective of the time of production and space, legacy is all planned and unplanned, positive and negative, tangible and intangible structures created for and by a sport event that remain longer than the event itself' (Preuss, 2007, p. 211). It has been a challenge for bidding cities to include many long-term effects of the Olympics that they scarcely believe themselves and are not working purposefully to fulfil. The organising committee disbands within two years after the event (Leopkey \& Parent, 2017), and it can be reduced to an academic activity to discuss positive or negative outcomes of different Olympic Games. Therefore, the purpose of this paper is to provide a long-term perspective on the 1994 Lillehammer Olympic Winter Games to also shed light on how legacies can develop over time. We conduct a comparison between what was promised in the application and what remains a quarter of a century later. We limit ourselves to sports facilities, an area of Olympic projects that seems to give the host region big challenges after the event. For example, Scheu et al. (2019) identified five 'winter cities' to which a rather negative sporting legacy was attributed, i.e. venues built for the Games remained empty or underused after the Games (Sochi 2014, Torino 2006, Nagano 1998, Sarajevo 1984 [venues also destroyed by the war] and Grenoble 1968).

With the 1994 Olympic Winter Games in Lillehammer as the case, the research question of this study is: How did Lillehammer prepare for a positive legacy of huge investments in sporting facilities for Olympic Winter Games in 1994? By increasing the understanding of an Olympic event in the 1990s, we fill gaps in the legacy literature. First, as pointed out by Thomson et al. (2019), legacy analysis has been done within a relatively short timeframe around the actual events. In their mapping of legacy literature, Bocarro, Byers, and Carter (2018) found that timeframes used to capture legacy rarely exceeded five years, which is in line with Scheu et al. (2019), who found in their review that the average time of post-Games data collection was two years after the event. Given that it takes 15-30 years to gain insight into the true legacy of an event (Gratton \& Preuss, 2008; Parent \& Smith-Swan, 2013), neither the 2010 FIFA World Cup in South Africa nor the 2012 Olympic Games in London (two events that have dominated the legacy literature) are suitable for retrospective studies. Koenigstorfer and colleagues (2019) stated that the'...length of time that legacy is assessed must be extended to years after the event to ascertain the longevity of legacies and weaknesses in legacy production over time' (p. 14).

Second, most event studies have been carried out on the Olympic Summer Games (Dickson, Benson, \& Blackman, 2011). More knowledge about the Winter Games is of importance because the investment in facilities is huge for areas that historically have been smaller than host cities for the summer Games. Such investment can pose special problems for hosts based in smaller communities (Essex \& Chalkley, 2004), who do not necessarily have the capacity to fund, digest and absorb major new developments or transport networks. Popa (2018) raises legacy to a more challenging standard for Winter Olympic Games than their Summer counterparts. This can be one reason for a decline in communities willing to host mega-events. The 2022 Winter Olympics turned into the 'Games that no one seems to want' (Associated Press, 2014) after Munich, Oslo, Stockholm, St. Moritz/Davos, Krakow, and Lviv refrained from submitting bids or withdrew them (Müller, 2015). More knowledge about legacies of the winter edition of the Games may give some answers. This paper is a contribution to fill this gap.

The paper proceeds as follows: First, a short overview of the 1994 Lillehammer Games is presented. Then the concept of legacy is explained. Then we present our findings and discussion, and some concluding remarks.

\section{The Lillehammer context}

In the early 1980s, the Norwegian government believed that the long-term outlook for business and jobs development in the inland districts was unpromising. The regions of Hedmark and Oppland (then 2 of 19 counties in Norway) were in the shadows of the increasingly attractive oil industry on the country's west coast. In August 1981, a committee (the Inland Committee) was appointed to look into what could be done to promote business and secure jobs in the inland districts. The Inland Committee stated that there was a need for 'special incentives' in the region (NOU, 1983: 21). At the same time, the idea of an Olympic event was seen as such an initiative, because it could stimulate the existing businesses, adding new expertise and new industries to the region. The Parliament's justification for giving a state guarantee was that it expected long-term outcomes, such as an increase in tourism, more jobs, better infrastructure and sport facilities [Hanstad, 1991; Lesjø, 2003; St. prp. nr. 85 (1984-1985)]².

The Lillehammer Games came about at a time when legacy-oriented planning was not yet institutionalised in the Olympic movement. Still, the thinking about post-Olympic use was an important background behind the initiative. Lillehammer promoted its bidding campaign under the slogan "Compact Games" to comply with the IOC's priorities at the time. Its campaign for the 1992 Winter Games resulted in a loss to the candidature of Albertville at the IOC session in Lausanne in October 1986. At the same session, another decision of considerable importance for Lillehammer was taken: the Olympic cycle for the Olympic Winter Games, which had followed the summer Olympics since 1924, was now changed to take place halfway into the period of the Olympiad (the four years between each edition of the Summer Games). This shift mainly came about for commercial reasons, as an initiative from TV companies convinced president Samaranch that the revenue from the Games would be larger if the Summer Games and Winter Games were split up (Payne, 2005, pp. 41-43). The next Winter Games was then set up to be delivered only two years after the 1992 Games. This gave the Lillehammer campaign a 'flying start', and the IOC awarded the city the 1994 Games in September 1988. Lillehammer then had the advantage of being the first Games to be the only Olympic event in

2 St. prp. is in English Proposition to the Parliament. 
the new Olympic calendar for the year 1994. The preparation for the Games took place at a time of international turmoil and was influenced by the dissolution of the Soviet Union, a number of new nations aspiring to enter the Olympic movement, and the Yugoslav Wars.

Chappelet (2002) has pointed out the challenge of the large growth of the Olympic Winter Games between 1980 and 2002. Although the Winter Games was born in small mountain resorts, its development into a mega-event has increasingly resembled that of the Summer Games, and the opportunity to host the event has likewise been rewarded to large cities (e.g. Calgary, Nagano, Salt Lake City and Turin). By contrast, small sites such as Albertville in France's Savoie region and Lillehammer have stood out as modern exceptions.

The delivery of the Olympic Winter Games in 1994 as a successful Games was a contribution to the Olympic movement and an intangible legacy of what a well-organized mega-event could demonstrate. Lillehammer's delivery of the Games was due not only to the organizers but also to a combination of organization and good luck. Namely, Lillehammer experienced the longest period of stable high pressure with sunshine for the month the Olympics took place. The accumulated interest in winter sports among Norwegians and the tradition of cheering on national heroes as well as competitors from other nations were also important for the atmosphere. The compact location attracted people to events, as Chappelet (2008) argued as the advantage of small places and concentrated events. The small town and its neighbour municipalities were the sites, and the enthusiasm of the public that filled the Olympic venues created a special festival atmosphere. A sense of belongingness and communitas among the spectators, visitors and locals was created, similar to what other events have attained (Chalip, 2006; Hiller, 2012).

\section{Legacy as a concept and analytical framework}

The word 'legacy' was first used in an Olympic document for the Games in Melbourne in 1956 (Leopkey \& Parent, 2012), but it was not until the 2000s that the terms 'legacy' and 'governance of legacy' were introduced by the IOC. Since 2003, 'legacy' has been included in its Charter, which states that the IOC's role is to promote a positive legacy from the Olympic Games to the host cities and host countries (IOC, 2013b, p. 17). All bidding cities have to present a plan for legacy, including the long-term benefits for the city, region and country. They must show how the bidding country can contribute to the development of the Olympic Movement and the Olympic Games (IOC, 2013a, p. 47). The IOC (2017) later developed a Legacy Strategic Approach with a roadmap for implementation and how legacy should be embedded in the lifecycle of the Games, from vision to the postgame period. Leopkey and Parent (2017) presented four event legacy phases set against Parent's (2008) event organization modes (in parenthesis): Legacy conceptualization (bid), legacy planning (planning and implementation phase), transfer/transformation (wrap-up), and post-Game legacy.
Legacy is defined in a number of ways; see, for example, Thomson, Schlenker, and Schulenkorf (2013) for a summary of the definitions. The definition presented by Preuss (2007) can be used as a point of departure for this essay. As mentioned previously, he defined the term as 'planned and unplanned, positive and negative, tangible and intangible structures created through a sport event that remain after the event' (p. 211). Preuss has expanded his definition of legacy from 2007. In a recent publication (Preuss, 2019), he states that legacy is any outcome that affects people and/or space caused by structural changes that stem from the Olympic Games. For a practical application, he adds that this legacy can be translated as:

(a) people (or several stakeholders) are affected by and/or

(b) the environment (city and nature) is affected by

(c) changes (tangible or intangible) that are

(d) caused by the Games (often developed indirectly by the Games).

(e) The outcome can be neutral, positive or negative. A negative legacy reminds us that outcomes may be unintentional (intention) (Preuss, 2019, p. 106).

The literature distinguishes between the terms legacy, leverage and impact. Impacts are outcomes that are directly connected to the staging of the event (Gratton \& Preuss, 2008). Leveraging means implementing measures to optimise desired event outcomes (Chalip, 2004). Leverage includes the evaluation that takes into account the stages of event cycle: bidding, planning and implementation of the event (Chalip, 2006). Taks, Chalip, and Green (2015) claim that a distinction between leverage and legacy is important. Legacy planning is concerned with the outcomes of an event that are rendered for the community, while leverage'focuses on the community and the ways that it can integrate each event into its marketing and management strategies' (Taks et al., 2015, p. 1).

As an analytical framework, Chappelet (2006) distinguished the legacies as sporting, economic, infrastructural, urban, and social. Grix, Brannagan, Wood, and Wynne (2017) derived five often overlapping categories: economic, urban regeneration, national pride/feel-good factor, increased participation in physical activity and sport, international prestige, and 'soft power'. In developing a new analytical framework for measuring legacy, Preuss (2019) emphasises that legacy is about structural changes that occur for and by the Games. According to him, legacy can be assigned to six facets: urban development, environmental enhancement, policy and governance, human development, intellectual property, and beliefs and behaviour. In our study urban development is under scrutiny, with emphasis on infrastructure/sporting facilities.

\section{Review of literature}

Compared to the Olympic Summer Games, only a small number of articles have been published related to the Winter Olympics (Dickson et al., 2011). Scheu et al. (2019) found that 18 per cent of the papers addressed the legacy of the Winter Games. Most of these studies have been on planning or expectation of legacies before the Games, or conducted within a short timeframe of the event. In 
the following, we narrow the review to facilities. While some longitudinal studies of facilities exist, a majority of the papers are commentary (Scheu et al., 2019). In this section, we will look at events that were held from 1988 to 2006, a period in which actual legacy is possible to assess.

Calgary 1988: Ritchie's (2000) paper on Calgary 1988 emphasized that the city and its institutions (most notably the University of Calgary) were the beneficiaries of many physical facilities that remain as invaluable assets to city residents. Second, and perhaps the most prized, legacy of the Calgary Games was a financial endowment fund containing sufficient financing to operate the facilities 'in perpetuity'. Hiller (2006) states that the facilities built for the 1988 Olympics have had mixed residual value in promoting the city. The hosting of occasional World Cup ski jump competitions and the legacy of the buildings as visible landmarks and training sites are important but have limited value as marketing tools for the city.

Albertville 1992: Following a few adaptations, the facilities remained true to their sporting vocation by continuing to host national and international events. They became quite attractive to tourists, apparently due to their Olympic image, and this helped them break even. The sport facilities were still working (apart from the speed skating ring) in the first part of the 2000s (Charmetant, 2002; Terret, 2008).

Lillehammer 1994: According to Chappelet's (2003) overview of Olympic Winter Games legacy, the ski jumps have not been used regularly, whereas Hamar Hall (the 'Viking ship') has been satisfactorily used for trade fairs, concerts and sport competitions. We will return to these commentary statements in the results of this paper.

Nagano 1998: According to Takao (2018), Nagano's sport facilities are too huge and expensive to be maintained within the village finances. Thus, it appears that local politicians and staff of sports associations planned the after-use of the facilities insufficiently. One example is a baseball stadium that was built for the opening and closing ceremonies. It remains empty (Zimbalist, 2015).

Salt Lake City 2002: Supporters of the 2002 Games publicly articulated the argument that investing in sports facilities was intended to make Utah the 'winter sports capital of North America' and not merely a way to land the Games. Thus, even before SLC had a serious bid effort underway, the conditions were in place for conceptualizing an Olympic legacy (Andranovich \& Burbank, 2011). Overall, the 2002 Olympics created a legacy for the host city and state that is ultimately a political product. In part, this tangible legacy was a product of the commitment of public resources prior to securing the Games that led political leaders to create a rationale for the use of tax money and to articulate the need for a legacy before the IOC included this criterion. Furthermore, the state and city attempted to leverage the Games to continue to attract sporting events to the metropolis as part of the tourist mix. After the 2002 Games, area governments and local businesses created the Utah Sports Commission to lure sports-related events to the state.

Torino 2006: The ski-jump complex in Pragelato and the bobsleigh track in Cesana have become 'white elephants' (Stimilli, Šæitaroci, \& Sargolini, 2016). The two ice stadiums in Torre Pellice and Pinerolo remain underused, with very high maintenance and management costs.

\section{Methods}

This paper is based on a single case study. Case studies are particularly useful for exploratory studies trying to answer how and why something happens (Yin, 2014). As Denscombe (2017) argues:

The logic behind concentrating efforts on one case rather than many is that there may be insights to be gained from looking at the individual case that can have wider implications and, importantly, that would not have come to light through the use of a research strategy that tried to cover a large number of instances (p. 57-58).

A benefit of case studies is their ability to incorporate a variety of different sources of evidence (Yin, 2014). The combination of methods enables us to analyse the topic more thoroughly than would have been possible by means of a single method (Silverman, 2001). In this study, research was mainly collected through documents and supplemented by interviews.

The documents included reports/investigations at the local and national level (5), bidding documents from the Lillehammer municipality and the Norwegian Olympic Committee to the Parliament and the IOC (4), application for state guarantees from Lillehammer municipality (3), propositions to the Parliament (8), minutes of meetings in the Parliament (4), Official Norwegian Report (NOU) (4), and the final report from the Lillehammer Organizing Committee (1).

To increase our understanding and insight, and to fill some gaps in the documents, in June 2020, we conducted one interview with two representatives involved in the bidding process and planning for the Games. Arne Myhrvold (born 1945), represented the Norwegian Olympic Committee (NOC) as vice president (1986-1989) and president (1989-1999). From 1988 to 1994, he was vice president of the Lillehammer Olympic Organizing Committee (LOOC). Hans B. Skaset (born 1935), was president of the Norwegian Confederation of Sports (NIF) from 1984 to 1990, and from 1991, he was Director-General in the Department of Sport (Ministry of Culture) and involved in the preparation from the government's side. As NIF president, he was a member of the bidding committee (1987-1988). He was a member of the LOOC from 1988 until he resigned as NIF president in 1990. The interview with Myhrvold and Skaset, key persons in the phase when the Lillehammer project transformed from bidding to preparation, made it possible to ask about topics that are not part of the official documents and to get more insight in the change of location of the sport venues. The bidding process started in the early 1980s and was led by men in their 50s and 60s. The two presidents of the NOC until 1988 (when Lillehammer was awarded the Games), and the head of the bidding committee (and the first president of the organizing committee) have passed away, while other key persons were not available due to health conditions. However, one of the authors interviewed all of them in 1990-91. ${ }^{3}$ 
We have therefore supplemented the data with nine of these transcribed interviews (including two prime ministers, three ministers of culture, two key politicians in the Parliament and the two leading people in Lillehammer's bid committee).

This brings us to a point that may be raised with regards to the content and quality of the data. The fact that Lillehammer was awarded the Games more than 30 years ago may play in different directions. Regarding internal validity, the empirical story we tell as well as the analysis we make do not have internal discrepancies. It is therefore important to bear in mind that participants may have different experiences of what really happened. In that respect, we have to be aware that we may not get the full picture of all aspects of the case. The choice to conduct interviews with two key actors together more than 30 years after Lillehammer was awarded the Games was so they could correct each other with regard to memory. The interviews from 1990-91 are useful (also from a methodology viewpoint) as a supplement because they were conducted after the facilities were finally located and financed, but before it was known whether the Olympics would be successful.

Data was analysed using standard methods of exploring (Miles, Huberman, \& Saldaña, 2014). We conducted a two-stage analysis. First, we concentrated on the following four points: Lillehammer's venue planning in the bidding phase, different stakeholders' involvement, the involvement of the Parliament, and how the strategies regarding sporting facilities post-Games influenced the legacy until today. Second, based on the first stage, we discussed how the process fits in with today's requirements regarding legacy and analytical frameworks. Our findings and discussion are presented in the following section.

\section{Findings and discussion: The Lillehammer 1994 legacy}

To find an answer to how Lillehammer prepared for a positive legacy resulting from the huge investments in sporting facilities for Olympic Winter Games in 1994, our starting point is to present how the sporting venues were located (picture to the right in Figure 1) compared to how it was presented in the bid (left). As will be shown, the change in locations is probably one of the key aspects for a rather positive legacy. We divide this section into three phases by starting with the bid phase (1981-1988), continue with transformation after the Games was awarded in 1988, and then discuss the post-Games period.

\section{Phase 1: Local initiative - a compact and concentrated concept}

Lillehammer as a possible Olympic host was first presented to the Lillehammer Municipal Council in January 1982 (Lillehammer kommune, 1982). The process for the next six years, including several working committees, investigations, political discussions and decisions at the local and national level, and the promotion of the bid
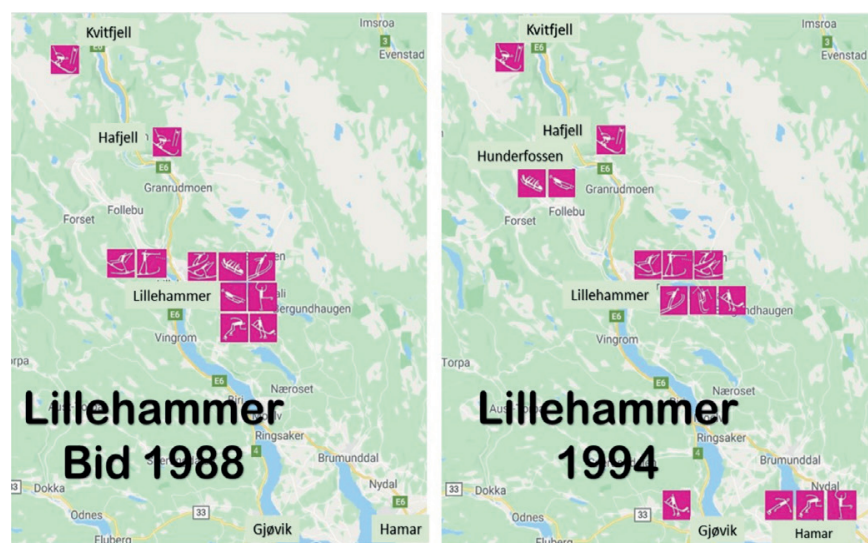

Figure 1. Lillehammer's venue concept in the bid and at the time of the Games. Distances: Lillehammer - Hamar (54 km), Lillehammer - Kvitfjell (45 km).

at different levels, can be summed up in Lillehammer's bid book to the IOC for the session in Seoul, Korea, September 1988:

Lillehammer's natural surroundings make it possible to concentrate all the events a very limited area. First, all athletes, coaches and managers will be assembled in one village in the heart of the Olympic area. Secondly, a number of sports arenas and other facilities will lie within walking distance of the Olympic Village (Lillehammer Olympic Association, 1987a, p. 19).

A compact Games Model was a core of the strategy for the 1994 Games, as it had been for the 1992 bid that failed. A prerequisite for applying for the Olympic Games is financial guarantees from the state authorities. One would expect that politicians at the national level saw a need to spread facilities over a larger area to secure a better after-use, or what would be a part of the legacy plan in today's Olympic project plan terminology. Instead, in its proposition to the government in 1985 (for the 1992 Games), the Ministry of Culture and Science narrowed itself to economic considerations:

Economic reasons for increased proliferation can hardly be stated. Arena expenses make up only $1 / 6$ of the estimated total costs [....] The probability is that increased diversification will increase rather than reduce total expenses, as any smaller expenses for arenas will be offset or exceeded by other infrastructure costs (St. prp. nr. 85 (1984-1985)).

Later that same spring, the state guarantee was discussed in the Parliament. The discussion in the Parliament was marked by many statements and allegations, based on documents characterized by great uncertainty and lack of quality control. For example, the proposition to the Parliament in 1985 stated that the cost estimates from the Lillehammer Municipality were 'based on sketchy plans and rough costs' (St. prp. nr. 85 (1984-1985), p. 4). This was repeated two years later when Lillehammer again applied for a state guarantee, this time for the 1994 Games. At the IOC Session in Lausanne 1986, where Lillehammer was defeated by Albertville (and Sofia and Falun), the IOC decided to hold the Summer and Winter

3 Both authors were involved in research on the policy process of the 1994 Lillehammer Games (not specific on legacy and facilities). 
Games in different years in a move aimed at focusing more attention on the winter events. For the new campaign, Lillehammer made just a few adjudgments in the concept. Almost all the sport facilities were located within a few kilometres in a town with less than 24000 inhabitants. For example, four indoor ice rinks were planned in the Olympic Park, including two halls to be dismantled after the Games. One key venue was late in the 1992 campaign included in the concept: a downhill (only for men) at Kvitfell, 45 $\mathrm{km}$ north of Lillehammer.

To sum up phase 1 (the bidding): It was a local initiative with people involved who saw this as a possibility for Lillehammer. As we will come back to, hardly any national politicians saw the project as realistic. With that perspective, it was easy to accept the premises (also regarding sports venues) without going into details. This should be changed.

\section{Phase 2: National and international involvement}

Lillehammer was awarded the 1994 Olympic Winter Games in September 1988 at the IOC session in Seoul, Korea. The host contract was signed by the IOC, the Lillehammer Municipality and the Norwegian Olympic Committee, based on the venue plan and the concept Lillehammer presented in its campaign and at the IOC Session. As late as June 1987, the Parliament home in Norway had adopted a state guarantee on 1.78 bill NOK (3.753 billion in 2020/0.35 bill. Euro). In 1990, the budget increased to 7 billion NOK (16.4 NOK in 2020 value/1.64 bill Euro). The sporting venue alone was estimated at 1.250 billion NOK (2.9 billion in 2020 value/0.29 billion Euro) - almost three times higher than approved in the state guarantee for the bid (St.prp. nr 1 (1990-1991)).

It is typical that sport venues turn out to be much more expensive than estimated in the financial guarantee from the government in the bid phase (Flyvbjerg, 2011). The peculiarity of Lillehammer is that the whole concept was thoroughly changed. First, the extremely compact concept from the application was abandoned (Figure 1), something that can be seen as unfair to the competing bidders (Anchorage, Östersund and Sofia) because one of Lillehammer's biggest advantages was its compactness. Second, almost all the facilities became larger and more expensive than what Lillehammer had presented a few years earlier (Table 1). To take two examples: An outdoor speedskating arena in Lillehammer was replaced by Hamar Olympic Hall, an iconic building constructed as a Viking ship turned upside down, with a capacity of 10500 spectators. Another example is one of the temporary ice halls in the Olympic Park, which was replaced by Gjøvik Olympic Cavern Hall, an ice rink with a capacity of 5300 located within a mountain. The cost explosion is classic in such projects (Alm, Solberg, Storm, \& Jakobsen, 2016; Preuss, Andreff, \& Weitzmann, 2019; Solberg \& Preuss, 2015). The Ministry of Culture's proposition to the Parliament (about the 1994 Olympic budget) stated that the Olympic project had changed because of increase in the number of athletes, events and media representatives (St.prp. nr 1 (1990-1991)). One important factor was new requirements from the international federations (IFs) to certify the facilities. IFs are responsible for organizing the competitions in their sports but have no responsibility for the financial obligations. These are with the host. This was clearly evident when the International Ice-Hockey Federation (IIHF) (supported by the Norwegian Ice Hockey Association) negotiated with the Lillehammer Olympic Organizing Committee (LOOC) about the ice hockey tournament. IIHF threatened to withdraw from the Games if new facilities were not built with an increase in spectator capacity of 50 per cent from the host contract (St. prp. nr. 1. Tillegg nr. 5 (1990-1991); St.prp. nr 1 (1990-1991)). Arne Myhrvold, vice president of the $\mathrm{LOOC}$ and the NOC, talked about the negotiations:

IIHF knew that they had the power to demand a lot from us. An Olympic Game without ice hockey was not an alternative. It gave an increase in expenditures but we had no choice. We sat also with the impression that the national special federation for ice hockey used IIHF's power to secure legacy in the form of new facilities for Norwegian ice hockey after the Games (June 2020 interview).

After hard negotiations, LOOC and IIHF came to an agreement which, among other things, entailed ice hockey's exclusive use of Håkon Hall and Gjøvik Olympic Cavern Hall (matches and training), increase in spectator capacity, and an obligation to use the hall for ice hockey after the Games. Finally, LOOC (and not the IOC) paid IIHF a compensation of 1,2 mill USD (2,36 mill USD in 2020 value) because the tournament increased from 12 to 16 days (St. prp. nr. 1. Tillegg nr. 5 (1990-1991)).

The huge increase in expenditure was a big concern for the Ministry of Culture. Without naming anyone, criticism was directed at the Lillehammer bid committee, the Lillehammer Municipality, sport organizations and the previous government for '...lack of identification or omission of costs; underestimation of costs and lack of assessment of the uncertainty in the project' (St.prp. nr 1 (1990-1991), p. 12). In the spring of 1990, when the redefined concept was discussed in the Parliament (the new budget at 7 billion NOK was approved autumn the same year), it was proposed to move many venues out of the region. Among the moves were ski jump to the Holmenkollen in Oslo (200 km from Lillehammer), bobsleigh and luge to Oslo or re-use of the venue in Albertville, and downhill to ski resorts as Oppdal and Hemsedal, far away from the region (Stortinget, 1990). Another suggestion, stated by the government, was to change the concept of the downhill in Kvitfjell to a temporary venue. Many politicians were critical, but they knew that there was no way back. Therefore, they decided to increase the budget for sport venues to ensure the best possible after-use. Indoor ice rinks in Hamar and Gjøvik were approved, and all venues previously decided and suggested as temporary were set to be permanent. Kjell Borgen, a senior member of the Labour Party (A) and former cabinet minister in two ministries, was involved in the whole process. When the wide-ranging changes were approved in 1990, he was the spokesperson for Olympic affairs in the parliamentarian committee.

I did not believe my own eyes when I saw that we were to arrange the event that most people in the world see, namely alpine [downhill], using military trolleys and helicopters that would transport the skiers from the finish area in Ringebu and up to the top of the mountain. I also did not think it was possi- 
ble to take care of the environment through, for example, temporary urinals and toilet facilities which would then be drained into cars and driven away in the dead of night. I think there was a lot here that did not seem very serious (April 1990 interview).

Borgen supported the local and regional interests, which from early on had directed their attention towards the after-use situation of the investments in new sport facilities. The establishment of an endowment fund for the post-Olympic period was one of their priorities. In the government guarantee before Lillehammer was awarded the Games, the fund was set to NOK 55 million (St. prp. nr. 87 (1986-1987)). With higher ambitions and new and more realistic budgets, there was also a need for more generous grants for the post-Games period. With that background, the central government established a model which should give incentives for such an increase. The mechanism established consisted of both a larger amount in the Olympic budget - as well as a share of expected extra incomes and untapped parts of the reserve fund which could be used for after-use purposes.

In the end, the endowment fund in 1994 reached the level of about NOK 400 million. A relatively small part was used for investments in the years up to 1994 to improve the post-Games potentials of the venues. The remaining resources were divided into local funds and a regional one; the former transferred to the local owners of the new sport facilities and the latter directed for industrial development, especially projects in the tourism sector.

To sum up: The decision to spread the facilities in several cities provided a basis for securing a positive legacy of the Olympic Games in Lillehammer. The involvement from major interests in sport and politics were far more comprehensive, and involved expertise from the national business community. The second factor was the establishment of a post-use fund that made it possible to ensure the maintenance and necessary upgrades of the facilities.

\section{Phase 3: Lillehammer Post-Games 1994}

At the end of the 1994 Games, 11 new sports facilities with a value of 1,25 billion NOK (2,2 billion NOK in 2020 value, 220 mill euro) remained (Langkaas, 1997). Included were four new ice halls, a ski jump (two hills), a speed-skating hall, bobsleigh and luge tracks, two slopes for alpine skiing, cross-country skiing/biathlon and an arena for freestyle skiing.

The operational responsibilities for the post-Games use of the new sport facilities have been transferred to the local level. The owners of the venues are local municipalities when it comes to the arenas in the Lillehammer Olympic Park and Hamar and Gjøvik, respectively. The organization of these ownerships is through limited companies, established at arm's length from the local government's ordinary activities. An exception from the public ownership is the alpine venues in Hafjell and Kvitfjell, which are owned by a private consortium today. After several changes in interest constellations, today, the Alpinco Group is responsible for operating the venues on a commercial basis through a couple of companies, with Hafjell Kvitfjell Alpin Ltd. as the event organiser.
Three of the Olympic venues have status as national venues: speed skating (the Viking ship) and alpine in Hafjell and Kvitfjell. Having status as a national venue means extra funding for investments (in addition to the after-use fund) from the Ministry of Culture as a post on the distribution of lottery money (Norwegian sport receives state funding mainly from the state-owned lottery). Also, cross-country skiing (Birkebeineren Ski Stadium), bobsleigh and luge (Hunderfossen), and the ski jump (Lysgaardsbakkene) are being maintained in accordance with international standards in the various international sport federations because of the after-use fund and extra funding from the state due to Lillehammer serving as host of the Youth Olympic Games in 2016 (Prop. 153 S (20102011)). The facilities are regularly used for international competitions. The figures covering the 25 years from 1993 to 2018 illustrate these: 32 World and European championships events in the Olympic venues, as well as 129 World Cup events, 74 national championships, 162 national cups and 478 regional or mass sport events (LOLSC, 2019). Examples limited to 2019 and 2020: World Cup ski jumping (two times each winter), Nordic combine, cross-country skiing, luge, alpine (downhill, super-G) and European championship in speed skating. In 2021, Lillehammer will host the World Para Snow Sports Championships. All the venues for skiing are at the calendar for World Cup organized by the International Ski Federation (FIS) in the years to come.

Some of the arenas are (also) used for sports other than those for which they were built. For example, Håkons Hall (ice hockey in 1994) has hosted the world championships in handball, European championships in taekwondo, and large festivals. Mainly, the facilities are used for training for both top athletes and recreational sports, including three handball surfaces that are used for many sports, a climbing wall, a running track, and a health club. Nevertheless, far cheaper facilities than an ice hockey hall with an audience capacity of 10,500 could have been built for these activities. Yet, without these costly arenas, Lillehammer would never have been awarded the Games.

Other facilities are probably more in use for sport than expressed in the bidding phase and the first part of the post-Games phase. For example, in the 1980s, ski jumping was purely a winter sport, and the Lysgårdsbakkene was seen as a potential 'white elephant' as also indicated by Chappelet (2003) nine years after the Games. Due to a modernization of the big hill in 2007 (partly by the afteruse fund), which included snow production, artificial surfaces and other requirements, Lysgårsdbakkene is in use 12 months a year. The annual number of ski jumps is estimated to 100000 (80 000 in the winter and 20000 during the summer) (Olympiaparken, u.å). To sum up: More than 25 years after the Games, the construction portfolio has been well managed and used by the IOC (2013b) to show best practices. This is in contrast to many other former Olympic cities whose arenas built for the Games have been abandoned and referred to as 'white elephants' in the event literature (Scheu et al., 2019). An obvious reason is the decisions taken by the national politicians in phase 2 by spreading the Olympic venues more than in the bidding phase, and to include a much larger after use fund. 


\section{Planned or unplanned?}

Going back to the legacy definition by Preuss (2007), the findings show that the sporting venues of the 1994 Olympic Winter Games in Lillehammer represent a positive and tangible legacy. But was it planned? The answer is in some ways 'yes', but what appears to be a planned, rigorous process for a positive facility legacy was not at all so in the bidding process, termed the Legacy conceptualization by Leopkey and Parent (2017). The local-based initiators and politicians who processed and approved the application for a state guarantee before Lillehammer was awarded the Games did not plan for a (venue) legacy other than purely rhetorically and narrowed to the municipality of Lillehammer. If all the venues for sport on ice and snow (except the alpine disciplines) had been located in a small town with 24000 inhabitants in 1994, an obvious result would have been 'white elephants. Therefore, is it the case that Lillehammer has a positive legacy despite cursory planning in the initial phase and solely due to coincidences and more seri- ous involvement of national stakeholders after Lillehammer was awarded the Games? The status of the Olympic sporting facilities, including a comparison of what was in the bid, Games time and the status today is summarized in Table 1.

By spreading the facilities to a much bigger regional area and increasing the after-use fund, it has been possible to maintain the venues. A third factor, which may be seen as a surprise, is that the Parliament decided to choose a more expensive venue plan than needed when the final Olympic budget was approved in 1990. All sporting facilities planned as temporary were replaced by permanent venues. They chose architectural solutions, which meant iconic facilities that were more expensive than they needed to be. Examples of this are the 'Viking Ship' and the 'Cavern Hall' - two facilities that could have been built much cheaper if the politicians had wanted it. Instead, they choose extra investments in venues that would give TV viewers around the world an impression of modern Norway and be facilities that could benefit the local population (not just for sports) in the future.

Table 1. Planned venues of the 1994 Olympic Winter Games in Lillehammer (Lillehammer Olympic Association, 1987b); how the venues were located (LOOC, 1995); and the status in 2020.

\begin{tabular}{|c|c|c|c|}
\hline Sport & Bid document 1988 & Game time 1994 & Status 2020 \\
\hline Alpine skiing & $\begin{array}{l}\text { Hafjell (18 km). All disciplines ex- } \\
\text { cept downhill and Super G } \\
\text { Kvitfjell (White Mountain) ( } 45 \text { km). }\end{array}$ & $\begin{array}{l}\text { As in the bid } \\
\text { Hafjell Alpine Centre. } \\
\text { Capacity: } 30000 \\
\text { Kvitfjell Alpine Centre. } \\
\text { Capacity: } 41000\end{array}$ & $\begin{array}{l}\text { Annual World Cup (Kvitfjell), Junior } \\
\text { Championships (Hafjell). Both are } \\
\text { tourist destinations }\end{array}$ \\
\hline $\begin{array}{l}\text { Biathlon and Cross } \\
\text { country }\end{array}$ & Faaberg, (5 km) & $\begin{array}{l}\text { Birkebeineren Ski Stadium, (3 km). } \\
\text { Capacity biathlon: } 13500 \\
\text { Capacity cross-country: } 34000\end{array}$ & $\begin{array}{l}\text { Biathlon: National competitions } \\
\text { Cross country: Annual World Cup } \\
\text { and reg/nat. competitions. }\end{array}$ \\
\hline Figure skating & $\begin{array}{l}\text { Indoor ice rink in Lillehammer } \\
\text { Olympic Park ( } 1 \text { km) } \\
\text { Capacity: } 3000\end{array}$ & $\begin{array}{l}\text { Hamar Olympic Amphitheatre } \\
(54 \text { km). } \\
\text { Capacity: } 6000\end{array}$ & $\begin{array}{l}\text { Home venue of Storhamar Hockey, } \\
\text { elite level }\end{array}$ \\
\hline Ice hockey & $\begin{array}{l}\text { Three indoor ice rinks in } \\
\text { Lillehammer Olympic Park (in ad- } \\
\text { dition to the hall for figure skating } \\
\text { also in use for ice-hockey (see } \\
\text { above) } \\
\text { Capacity: } 10000,700,700 \text { specta- } \\
\text { tors }\end{array}$ & $\begin{array}{l}\text { Two indoor ice rinks in Lillehammer } \\
\text { Olympic Park: Håkons Hall } \\
\text { Capacity: } 10500 \\
\text { Kristin Hall (for training) } \\
\text { Gjøvik Olympic Hall } 45 \mathrm{~km} \text { ) } \\
\text { Capacity: } 5300\end{array}$ & $\begin{array}{l}\text { Lillehammer: Håkons Hall for com- } \\
\text { petitions in various sport. Training } \\
\text { for mass sport. Kristin Hall home } \\
\text { venue of Lillehammer Hockey, elite } \\
\text { level (cap 3500). } \\
\text { Gjøvik: Ice-hockey and handball }\end{array}$ \\
\hline Short track & Not in the bid & $\begin{array}{l}\text { Hamar Olympic Amphitheatre } \\
(54 \mathrm{~km}) . \text { See above (figure skating) }\end{array}$ & See above (ice-hockey) \\
\hline Ski jumping & Balberg (3 km) & $\begin{array}{l}\text { Lysgaardsbakkene Ski Jumping } \\
\text { Arena. Also for opening/closing } \\
\text { ceremony } \\
\text { Capacity: } 35000\end{array}$ & $\begin{array}{l}\text { Annual World Cup men and } \\
\text { women. Artificial grass for summer } \\
\text { ski jumping. }\end{array}$ \\
\hline
\end{tabular}


As shown by Leopkey and Parent (2017), a legacy process includes different actors, and they change during the event's life cycle. The same authors emphasize that legacy planning should be part of the cycle from the conceptualisation phase to the post-Games phase. Initially, legacy planning should be about maximizing support from other Games stakeholders, including the public and the government/Parliament. As shown in the previous section, the Lillehammer idea obtained support early in the 1980s partly because some key stakeholders did not take the idea seriously. Many decision-makers hardly expected that there would be any Olympics in Lillehammer, and therefore they did not take seriously what the initiators presented as positive outcomes. Some examples:

I must admit that it was difficult to get a picture of the extent to which this event would actually take place, and to what extent the state should commit itself financially. One can get the impression that the people of Lillehammer also knew less than they really should have known (Kåre Willoch, Prime Minister 1981-1986, April 1991 interview).

I did not really reflect so much on the question because I did not take the matter seriously (Kjell Borgen, member of the Parliament. Later key spokesperson when the Parliament settled the new concept and budget in 1990. April 1991 interview).

The commitment in the Parliament could seem modest. The Games was far in the future, and most felt that it would hardly be awarded to Norway even if one applied (Tore Liltvedt, Member of Parliament. May 1991 interview).

Our analysis of the negotiations in the Parliament in 1985 (for the 1992 bid) shows that mainly local representatives and/or backbenchers were involved. Here, a backbencher is defined as a member of the Parliament who has no central position in his/her political party or in any committee in the Parliament. No 'heavyweights' (former/current ministers or people with key positions in their parties) were involved. Fifteen representatives (of 157) took part in the debate on May 22, 1985. Six of them were members representing Oppland (the host county). No representative from the neighbouring county, Hedmark (which ended up with two ice halls in Hamar), took part (Stortinget, 1985). The debate two years later (for the 1994 bid), though a few national politicians took the floor, was mainly a repetition with little engagement. Prime minister Gro Harlem Brundtland, who had a key role in Seoul 1988, said:

The case was perceived as a local initiative from Lillehammer where the nation was to give its support exclusively through a guarantee. Thus, it became the case in the Parliament that first and foremost the local representatives got involved (May 1991 interview).

It may seem surprising that, back in the 1980s, an Olympic event was seen as something local that politicians from the area and backbenchers approved. This changed with the debate for a revised concept after Lillehammer was awarded the Games. More profiled politicians with key roles in their parties took part, and representatives from 16 out of 19 counties participated in the dis- cussion in the Parliament (Stortinget, 1990). In this debate, based on the proposition for venue localisations and new cost framework (St. prp. nr. 61 (1989-1990)), venues were a core element. It was suggestions that venues should be moved to existing facilities in other parts of Norway (also to re-use bobsleigh and luge in Albertville). What ended up as a conclusion was to build new and more costly venues than planned by the local initiators, but not only in Lillehammer. This speech by Tore A. Liltvedt represents a majority of views:

The Mjøsa district will be the Olympic arena. This means a distribution in Lillehammer, Gjøvik, Hamar, Øyer and Ringebu. The distance between these different urban and rural municipalities is very affordable [...] I think the proposed arena locations provide a super mix. It gives the little extra not only during the Games, but also in terms of after-use. And the latter is not least important for people and business in this district (Stortinget, 1990, p. 3067).

What seems from the debate in the Parliament is that the politicians were less affected by the international federations than the Norwegian Confederation of Sports (NIF), which had an increasingly important role. NIF supported the campaign in the bidding phase but did not at first engage in venue localisations, which was something they left to the National Olympic Committee. According to NIF president (1984-1990) Hans B. Skaset, the NIF board gave support to the idea but never took the question of Lillehammer as an Olympic host to the General Assembly. It was only in the decisive phase before and during the IOC session in Seoul (1988) that NIF fully engaged. In the following two years, NIF was a key stakeholder to move different venues to locations other than Lillehammer - because of the after-use.

For us, it was important to ensure that the facilities would benefit children's and grassroots sports in addition to elite sport for many years after the Olympics. We would only be able to achieve this by using more cities than Lillehammer. Locally, there was great resistance, but eventually, the pressure was so great that Lillehammer municipality agreed to move some facilities (Hans B. Skaset, June 2020 interview).

The involvement by NIF, with the decisions that followed in the Parliament, is probably one of the keys to the positive legacy. Another is something pointed out by Alm et al. (2016); the formula for a successful venue investment seems simple, though: construct a new stadium in a place where a team that attracts large regular crowds already exists. Hamar and Lillehammer have teams at the elite level in ice hockey, which have regular use of the Hamar Olympic Amphitheatre and Kristin Hall ${ }^{4}$.

Time is an important consideration when discussing legacy. Bidding cities often list long-term effects of the Olympics they themselves hardly believe and are not working to fulfil. Additionally, it takes many years to measure the true legacy of an event. As we have mentioned, Gratton and Preuss (2008) estimate this to be at least 15-20 years. One year after the 1994 Winter Games, Håkon Hall and bobsleigh and luge tracks would have had significant financial challenges, had it not been for an after-use fund that was 
established, which generated approximately 400 million NOK (Heyerdahl, 2014). Annually, 12-13 million NOK have been spent on the facilities (8-10 m NOK in Lillehammer, and the rest to venues in Hamar, Gjøvik, Ringebu and to regional development in the Olympic region). In other words, what has been seen as a positive legacy has been dependent on considerable financial assistance. A Municipal Council representative from the Lillehammer Centre Party highlighted this in a recurring discussion on Lillehammer as Olympics host (for the Games in 2030 or 2034): 'The necessity of extraordinary state support (re-use funds) after the Olympics is in itself a proof that it is not profitable to organise the Olympic Games' (Hoven, 2016).

Most of the Olympic venues in the Lillehammer area are of too large a scale for ordinary local use. To keep the venues according to international standards, the owners are dependent on bringing activities into the venues to create income. Over the years, there has been a permanent endeavour to bring new events to the venues and a continuous run for large events - hopefully, one day also bringing the Olympics back to the region. Until today, however, it has been difficult to host international events with any surplus for the local organizers.

Preuss (2015) suggests that a positive perception of legacy can transform into a negative one and vice versa. He points to the example of a new stadium that could initially produce a positive economic legacy through increased tourism and the use of the arena for cultural events and other occasions. This, however, could turn into a negative legacy if the county or state does not financially support the facilities. This point is critical in the discussion around Lillehammer's legacy. The after-use fund has been depleted, and government funding has ceased. The Lillehammer Municipality has absorbed a significant part of the financial burden, with contributions from Oppland County and to some extent the state (national systems), but a protracted model has not been put in place.

\section{Concluding remarks}

In this article, we conclude that the sport facilities after the Olympics in Lillehammer left a positive legacy. The criteria for such a conclusion is that all the facilities are well maintained more than 25 years later, and they are used for elite and mass sports. Regarding the research question, how Lillehammer prepared for a positive legacy, the answer is less straightforward. In the initial phase, there was a lack of a thorough plan for sport venues. If the approved government's guarantee and venue plan in 1987 had been upgraded and not totally changed after Lillehammer was awarded the Games, , it is doubtful the legacy would have been entirely positive.

The Parliament's contribution to secure the building for the years to come was also a crucial part to ensure event legacy outcomes. What should be learned from the case of Lillehammer 1994 is that Olympic budgets must not only include a budget for legacy plan- ning, but also for securing their long-term effects. Hence, legacy planning must include strategies to secure long-term funds for securing positive legacy outcomes.

The sport venues built for the Lillehammer Olympics have experienced a wide-ranging use for national and international competitions in the post-Games period. The problem connected to 'white elephants' typically following large events did not occur. The unplanned regionalisation of the sport venues, compared to the bid concept, in many ways facilitated easier post-Games responsibilities for the host city. At the same time, the investments accelerated a legacy with better facilities for some sports. Due to more generous endowment funds than in the original plans, the Olympic park could develop in 20 years with a planned consumption of the fund's capital. However, after 25 years and with empty funds, the challenges for the host are now substantial. The many sport events in the Olympic arenas have been a delight, of course, for the sportminded people in the region, while other citizen segments prefer different events and another public city profile.

The example of Lillehammer's legacy is opposite of what Thomson et al. (2013) stated in their literature review, claiming that planning for legacy must take place at the conception of the event, rather than being considered as an afterthought; 'this means that legacy should be defined, responsibilities assigned, stakeholders identified, and strategies planned from the outset of the event' (p. 120). The authors also point out something that seems obvious; legacy needs to be defined from the earliest stages of the event, so that event managers, policymakers, and stakeholders have a clear vision for what is to be achieved (p.120). For Lillehammer, the process to fulfil the important legacy of the sporting facilities needed a complete change to have any possibility of being fulfilled. This happened years after the conception period started.

The case of Lillehammer will be interesting to follow in the years to come. For more than 25 years, the facilities have been taken care of - first and foremost with funding from the after-use fund. Now it is the responsibility of each municipality. Will they continue to finance the running costs (and necessary upgrading) of the venues with local taxpayers' money? The conclusion of the story might change.

\section{Acknowledgements}

The authors want to thank participants at the workshop on organisation and leadership at the NEON Conference (The Network for Organizational Research in Norway) in November 2019, and associate professor Bieke Gils for useful comments on an earlier draft. We also want to thank two anonymous reviewers.

\section{Funding}

The authors have no funding or support to report.

4 Kristin Hall has in 2020 a temporary name linked to a sponsor, Eidsiva Arena. 


\section{Competing Interests}

The authors have declared that no competing interests exist.

\section{Data Availability Statement}

All relevant data are within the paper.

\section{References}

Alm, J., Solberg, H. A., Storm, R. K., \& Jakobsen, T. G. (2016). Hosting major sports events: the challenge of taming white elephants. Leisure Studies, 35(5), 564-582. doi:10.1080/02614367.2014.994 550

Andranovich, G., \& Burbank, M. J. (2011). Contextualizing Olympic Legacies. Urban Geography, 32(6), 823-844. doi:10.2747/02723638.32.6.823

Associated Press. (2014). Ukraine's Lviv withdraws bid for 2022 Winter Games. USA Today. Retrieved from https://eu.usatoday. com/story/sports/olympics/2014/06/30/ukraines-Ivivwithdraws-bid-for-2022-winter-games/11736889/

Bocarro, J., Byers, T., \& Carter, L. (2018). Legacy of sporting and non-sporting mega event research. What's next? In I. Brittain, J. Bocarro, T. Byers, \& K. Swart (Eds.), Legacies and mega events: Fact or fairy tales? (pp. 7-24). London and Nwe York: Routledge.

Chalip, L. (2004). Beyond impact: A general model for sport event leverage. In R. B. W \& D. Adair (Eds.), Sport tourism: Interrelationships, impacts and issues (pp. 226-252). Clevedon: Channel View Publications.

Chalip, L. (2006). Towards Social Leverage of Sport Events. Journal of Sport \& Tourism, 11(2), 109-127. doi:10.1080/14775080601155126.

Chappelet, J.-L. (2002). From Lake Placid to Salt Lake City: The challenging growth of the Olympic Winter Games Since 1980. European Journal of Sport Science, 2(3), 1-21. doi:10.1080/17461390200072302

Chappelet, J.-L. (2003). The Legacy of the Winter Games: An Overview. In M. Moragas, C. Kennet, \& N. Puig (Eds.), The Legacy of the Olympic Games, 1984-2002 (pp. 54-66). Lausanne: International Olympic Committee.

Chappelet, J.-L. (2006). The tale of three Olympic Cities - forecast for Torino on basis of Grenoble and Innsbruck. Paper presented at the Torino 2006 - XX Winter Olympic Games Symposium, Turin.

Chappelet,J.-L. (2008). Olympic Environmental Concernsas a Legacy of the Winter Games. The International Journal of the History of Sport, 25(14), 1884-1902. doi:10.1080/09523360802438991

Charmetant, R. (2002). The Use of Olympic Installations after the Games: The Case of Albertville. In M. d. Moragas, C. Kennett, \& N. Puig (Eds.), The Legacy of the Olympic Games 1984-2000: International Symposium Lausanne, 14th, 15th and 16th November 2002 (pp. 145-164). Lausanne: International Olympic Commitee.
Denscombe, M. (2017). The Good Research Guide. London: Open University Press.

Dickson, T. J., Benson, A. M., \& Blackman, D. A. (2011). Developing a framework for evaluating Olympic and Paralympic legacies. Journal of Sport \& Tourism, 16(4), 285-302. doi:10.1080/147750 85.2011 .635014

Essex, S., \& Chalkley, b. (2004). Mega sporting events in urban and regional policy: a history of the Winter Olympics. Planning Perspectives, 19(2), 201-232.

Flyvbjerg, B. (2011). Over Budget, Over Time, Over and Over Again: Managing Major Projects. In P. W. G. Morris, J. P. Pinto, \& J. Söderlund (Eds.), The Oxford Handbook of Project Management (pp. 321-344). Oxford: Oxford University Press.

Gratton, C., \& Preuss, H. (2008). Maximizing Olympic impacts by building up legacies. The International Journal of the History of Sport, 25(14), 1922-1938. doi:10.1080/09523360802439023

Grix, J., Brannagan, P. M., Wood, H., \& Wynne, C. (2017). State strategies for leveraging sports mega-events: unpacking the concept of 'legacy'. International Journal of Sport Policy and Politics, 9(2), 203-218. doi:10.1080/19406940.2017.1316761

Hanstad, D. V. (1991). OL på Lillehammer: en prosessanalyse med særlig vekt på overveielser, beslutninger og tiltak $i$ det politiske system [The Lillehammer Olympics: a process analysis with particular emphasis on the deliberations, decisions and actions in the political system). (hovedfag/master). Norges idrettshøgskole, Oslo.

Haugerud, K. (2015). Arven fra Lillehammer [Leagy from Lillehammer]. Lillehammer: Lillehammer kommune.

Heyerdahl, G. S. (2014). Vinter-OL i skisportens vugge - De VI Olympiske vinterlekeri Oslo, 1952 og De XVII Olympiske vinterleker i Lillehammer, 1994 [Winter Olympics in the cradle of skiing - The VI Olympic Winter Games in Oslo, 1952 and the XVII Olympic Winter Games in Lillehammer, 1994]. (Phd). Norwegian School of Sport Sciences, Oslo.

Hiller, H. H. (2006). Post-event Outcomes and the Post-modern Turn: The Olympics and Urban Transformations. European Sport Management Quarterly, 6(4), 317-332.

Hiller, H. H. (2012). Host Cities and the Olympics. An interactionist approach. New York: Routledge.

Hoven, H. J. (2016). Noen gode grunner til at Lillehammer ikke skal søke om OL 2026 [Some good reasons why Lillehammer shall not apply for the 2026 Winter Olympics]. Retrieved from http://www.gd.no/debatt/leserinnlegg/senterpartiet/ noen-gode-grunner-til-at-lillehammer-ikke-skal-soke-om-ol2026/o/5-18-344779

IOC. (2013a). 2022 Candidature Acceptance Procedure. XXIV Olympic Winter Games. Lausanne: International Olympic Committee.

IOC. (2013b). Olympic Legacy. Lausanne: International Olympic Committee.

IOC. (2017). Legacy Strategic Approach. Moving Forward. Lausanne: International Olympic Committee.

Koenigstorfer, J., Bocarro, J. N., Byers, T., Edward, M. B., Jones, G. J., \& Preuss, H. (2019). Mapping research on legacy of mega sporting events: structural changes, consequences, and stakeholder 
evaluations in empirical studies. Leisure Studies. doi:10.1080/0 2614367.2019.1662830

Langkaas, L. (Ed.) (1997). Nasjonalatlas for Norge: Idrett [National Atlas for Norway: Sport]. Hønefoss: Statens Kartverk.

Leopkey, B., \& Parent, M. M. (2012). Olympic Games Legacy: From General Benefits to Sustiable Long-Term Legacy. International Journal of the History of Sport, 29(6), 924-943. doi:10.1080/095 23367.2011.623006

Leopkey, B., \& Parent, M. M. (2017). The governance of Olympic legacy: process, actors and mechanisms. Leisure Studies, 36(3), 438-451. doi:10.1080/02614367.2016.1141973

Lesjø, J. H. (2003). OL-saken: en prosess-sosiologisk studie av planlegging, politikk og organisering [The Lillehammer Olympics: a process-sociological study of planning, politics and organising]. (dr. philos). Høgskolen i Lillehammer, Lillehammer.

Lillehammer kommune. (1982). Vinter-OL 1992. En foreløpig utredning om muligheten for å arrangere vinterlekene $i$ Lillehammer. Sak nr. 57, Lillehammer kommunestyre 22. januar Lillehammer: Lillehammer kommune

Lillehammer Olympic Association. (1987a). Lillehammer, NorwayNorvège: Candidate to host the 1994 Olympic Winter Games. Vol.1: The Olympic Winter Games in Lillehammer. Lillehammer: Lillehammer Olympic Association. Lillehammer.

Lillehammer Olympic Association. (1987b). Lillehammer, NorwayNorvège: Candidate to host the 1994 Olympic Winter Games. Vol. 2: Organization Lillehammer: Lillehammer Olympic Association.

LOLSC. (2019). Overview of events in the Olympic venues up to 2018. Lillehammer: Lillehammer Olympic Legacy Sports Centre

LOOC. (1995). Olympic Winter Games official report Lillehammer 1994. Retrieved from Lillehammer: Lillehammer: Lillehammer Olympic Organising Committee

Miles, M. B., Huberman, A. M., \& Saldaña, J. (2014). Qualitative data analysis: an expanded sourcebook. Thousand Oaks, California: Sage.

Montville, L. (1994, March 7). “Once upon a time". Sport Illustrated, p. 90.

Müller, M. (2015). The Mega-Event Syndrome: Why So Much Goes Wrong in Mega-Event Planning and What to Do About It. Journal of the American Planning Association, 81(1), 6-17. doi:1 0.1080/01944363.2015.1038292

NOU 1983: 21. Næringslivets utviklingsmuligheter i Innlandet (Nordli) Innlandsutvalgets innstilling). Oslo: Universitetsforlaget

Olympiaparken. (u.å). About the arena. Retrieved from https:// olympiaparken.no/en/anlegg/lysgardsbakkene-hoppanlegg/

Parent, M. M. (2008). Evolution and issue patterns for major-sportevent organizing committees and their stakeholders. Journal of sport management, 22(2), 135-164. doi: 10.1123/jsm.22.2.135

Parent, M. M., \& Smith-Swan, S. (2013). Managing Major Sports Events. Theory and Practice. London and New York: Routledge.

Payne, M. (2005). Olympic Turnaround. Berkshire: London Business Press.

Popa, S. C. (2018). Earth Games. The 1994 Lillehammer Winter Olympic Games, or the Failure of the Ecological Project. ( Doctor in Philosophy). BArch Politechnic University of Catalonia
Preuss, H. (2007). The Conceptualisation and Measurement of Mega Sport Event Legacies. Journal of Sport \& Tourism, 12(3-4), 207-227. doi:10.1080/14775080701736957

Preuss, H. (2015). A framework for identifying the legacies of a mega sport event. Leisure Studies, 34(6), 643-664. doi:10.1080 /02614367.2014.994552

Preuss, H. (2019). Event legacy framework and measurement. International Journal of Sport Policy and Politics, 11(1), 101-118. doi:10.1080/19406940.2018.1490336

Preuss, H., Andreff, W., \& Weitzmann, M. (2019). Cost and Revenue Overruns of the Olympic Games 2000-2018. Wiesbaden: Springer Gabler.

Prop. 153 S (2010-2011). Statsgaranti og tilsagn om statlig tilskudd for å arrangere olympiske vinterleker for ungdom i 2016. Tilråding fra Kulturdepartementet av 30. september 2011, godkjent $i$ statsråd samme dag. . Oslo: Kulturdepartementet

Ritchie, J. R. B. (2000). Turning 16 days into 16 years through Olympic legacies. Event Management, 6(3), 155-165. doi:10.3727/096020197390239

Scheu, A., Preuss, H., \& Könecke, T. (2019). The Legacy of the Olympic Games: A Review. Journal of Global Sport Management, 1-22. do i:10.1080/24704067.2019.1566757

Silverman, D. (2001). Interpreting Qualitative Data. (2 ed.). London: Sage.

Solberg, H. A., \& Preuss, H. (2015). Major Sports Events: The Challenge of Budgeting for the Venues. Event Management, 19(3), 349-363. doi:10.3727/152599515X14386220874805

St.prp. nr. 1. Tillegg nr. 5 (1990-1991). Budsjett for De olympiske vinterlekene 1994. Tilråding fra Kirke- og kulturdepartementet 23. november, godkjent i statsråd samme dag. Oslo: Kirke- og kulturdepartementet

St.prp. nr. 61 (1989-1990). De 17. olympiske vinterleker på Lillehammer 1994. Arenalokaliseringer, m.v. Tilråding fra Kirke-og kulturdepartementet 9. februar 1990, godkjent i statsråd samme dag. Oslo: Kirke- og kulturdepartementet

St.prp. nr. 85 (1984-1985). Om statsgaranti til Lillehammer kommune $i$ forbindelse med søknad om å bli tildelt arrangementet av olympiske vinterleker 1992. Tilråding av Kultur- og vitenskapsdepartementet av 29. mars 1985, godkjent i statsråd samme dag. Oslo: Kultur- og vitenskapsdepartementet

St.prp. nr. 87 (1986-1987). Om statsgaranti m.v til Lillehammer kommune i forbindelse med søknad om å bli tildelt arrangement av olympiske vinterleker 1994. Tilråding fra Kultur- og vitenskapsdepartementet 10.april 1987, godkjent i statsråd samme dag. Oslo: Kultur- og vitenskapsdepartementet

St.prp. nr 1 (1990-1991). Budsjett for de olympiske vinterleker 1994. Tilråding fra Kirke- og kulturdepartementet av 28. september 1990, godkjent i statsråd samme dag. Oslo: Kirke- og kulturdepartementet

Stimilli, F., Šæitaroci, M. O., \& Sargolini, M. (2016). Turin, Sochi and Krakow in the Context of Winter Olympics. Spatial Planning and Territorial Impact of the Games. Prostor, 24(1), 74-89. doi:10.31522/p.24.1(51).6 
Stortinget. (1985). Statsgaranti til Lillehammer kommune i samband med søknad om å bli tildelt arr. av vinter-OL 1992. Behandling 23. mai 1985. Stortingstidende, 3854-3867.

Stortinget. (1987). Statsgaranti m.v til Lillehammer kommune $i$ forbindelse med søknad om å bli tildelt arrangement av olympiske vinterleker 1994 (Behandling 1. juni 1987).

Stortinget. (1990). Forhandlinger i Stortinget nr. 208. De 17. olympiske vinterleker på Lillehammer 1994. 23. april. Stortingstidende, 3063-3116.

Takao, M. (2018). The "legacy" of the Olympic Games for local communities A case study of the Nagano 1998 Winter Olympic Games. In I. Brittain, J. Bocarro, T. Byers, \& K. Swart (Eds.), Legacies and mega events: Fact or fairy tales? (pp. 189-198). London and New York: Routledge.

Taks, M., Chalip, L., \& Green, B. C. (2015). Impacts and strategic outcomes from non-mega sport events for local communities. European Sport Management Quarterly, 15(1), 1-6. doi:http:// dx.doi.org/10.1080/16184742.2014.995116

Terret, T. (2008). The Albertville Winter Olympics: Unexpected Legacies - Failed Expectations for Regional Economic Development. The International Journal of the History of Sport, 25(14), 1903-1921. doi:10.1080/09523360802439262

Thomson, A., Cuskelly, G., Toohey, K., Kennelly, M., Burton, P., \& Fredline, L. (2019). Sport event legacy: A systematic quantitative review of literature. Sport Management Review, 22(3), 295-321. doi:10.1016/j.smr.2018.06.011

Thomson, A., Schlenker, K., \&Schulenkorf, N. (2013). Conceptualizing Sport Event Legacy. Event Management, 17(2), 111-122.

Yin, R. K. (2014). Case Study Research. Design and Methods (4th ed.) (4 ed.). Thousand Oaks: Sage.

Zimbalist, A. (2015). Circus Maximus: The economic gamble behind hosting the Olympics and the World Cup. Washington, DC: Brookings Institution Press. 
